\author{
Daria Jagiełło, Magdalena Kumorowicz, \\ Paulina Szczurek, Kamila Witkowska \\ Wydział Sztuk Pięknych UMK, Toruń
}

\title{
Katalog architektury drewnianej Torunia - podsumowanie projektu Koła Naukowego Studentów Konserwatorstwa UMK
}

Toruń to miasto zabytków o międzynarodowej randze, czego znakiem i potwierdzeniem było wpisanie w 1997 roku jego średniowiecznego zespołu miejskiego na listę światowego dziedzictwa UNESCO ${ }^{1}$. Hasło Gotyk na dotyk i wszystko, z czym ono się wiąże, stało się wizytówką miasta, doskonale promując je zarówno w kraju, jak i poza jego granicami. Czy jednak w ostatecznym rozrachunku sukces ten nie przesłonił równocześnie pełnego obrazu Torunia i nie zepchnął wartościowej architektury kolejnych wieków jego rozwoju na margines? Jak można zauważyć, pytanie to coraz częściej zadawane jest przez

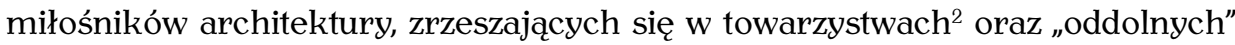
ruchach obywatelskich, mających na celu przede wszystkim ochronę i popularyzację niszczejących, mniej znanych zabytków Torunia.

Społeczne inicjatywy są obecnie najczęściej odpowiedzią na to, co dzieje się z niknącą w oczach szkieletową architekturą Torunia: niszczejącymi willami na historycznym przedmieściu Bydgoskim, wyburzanymi budynkami mieszkalnymi przy ul. Chełmińskiej czy obudowywaną kolejnymi blokami drewnianą zabudową flisaczą Winnicy. Oceniając ten stan rzeczy należy przecież pamiętać, że

1 Zob. http://www.unesco.pl/?id=290 (dostęp: 23 IV 2015).

2 W tym miejscu należy wspomnieć o Stowarzyszeniu Bydgoskie Przedmieście, zob. http:// bydgoskie.blox.pl/html (dostęp: 28 IV 2015). 30 I 2015 roku powstał także toruński oddział Towarzystwa Opieki nad Zabytkami; http://tonz-torun.pl/_(dostęp: 28 IV 2015). Inną inicjatywą tego typu jest nieformalna grupa zrzeszająca miłośników zabytków - „Thornrreadors”, zob. https://www.facebook. com/groups/1431343200431655/ (dostęp: 28 IV 2015). 
przywołana architektura jest typowa dla historycznych przedmieść toruńskich, których układ ukształtował się zasadniczo w XIX i na początku XX wieku, i niesie za sobą wyraźny przekaz dotyczący historii miasta. Wiązało się to z przyłączeniem Torunia do Prus w wyniku ustaleń Kongresu Wiedeńskiego (1815) oraz przemianowaniem go na twierdzę pierwszego stopnia ${ }^{3}$. Przepisy budowlane dla twierdz z 1814 roku zakazywały wznoszenia trwałej zabudowy w I rejonie fortecznym, dopuszczano budowę tylko niewielkich domów z lekkiej konstrukcji drewnianej lub szkieletowejł. Dlatego też znaczna ich liczba skoncentrowana wokół zespołu miejskiego w Toruniu to nie tylko przykład zróżnicowania architektury miasta na jednym z etapów jego rozwoju, ale przede wszystkim znak, odsyłający do historycznych uwarunkowań, które w znacznej - jeśli nie: zasadniczej - mierze określiły jego kształt i charakter.

\section{Krótki opis projektu}

„Katalog architektury drewnianej w Toruniu” powstał w latach 2011-2013 wysiłkiem członków Koła Naukowego Studentów Konserwatorstwa działającego przy Wydziale Sztuk Pięknych UMK. Jest on jednym z wielu działań odwołujących się do celów statutowych, jakie stawia przed sobą założone w 2011 roku Koło (podobnie jak wykonywane przez jego członków w ramach wolontariatu dokumentacje pomiarowo-rysunkowe czy akcje promujące, m.in. zajęcia dla dzieci i młodzieży, mające na celu zachęcić do zainteresowania się problematyką dziedzictwa). Katalog jest próbą fotograficznej dokumentacji zachowanych, ale ciągle niknących z przestrzeni miasta zabytków architektury szkieletowej i drewnianej. Projekt swym zakresem objął Toruń w jego granicach administracyjnych.

Pierwszym etapem działań Koła było nawiązanie współpracy z Miejskim Konserwatorem Zabytków (mgr Mirosławą Romaniszyn) - zaświadczenia wydane studentom biorącym udział $\mathrm{w}$ projekcie miały ułatwić pracę i zapobiec nieprzychylnym reakcjom właścicieli obiektów, trzeba bowiem wspomnieć o pewnej dozie nieufności, z jaką odnosili się oni do osób zaangażowanych $\mathrm{w}$ tworzenie Katalogu. $\mathrm{W}$ dużym stopniu wynikało to prawdopodobnie $\mathrm{z}$ obawy przed formą ukrytej urzędowej kontroli. Istotny problem stanowiły również wątpliwości pojawiające się przy interpretowaniu prawa własności czy istoty

3 Joanna KucharzewsKa, Architektura i urbanistyka Torunia w latach 1871-1920, Warszawa 2004, s. 20.

4 Uzasadnienie decyzji Kujawsko-Pomorskiego Wojewódzkiego Konserwatora Zabytków z dnia 25 VII 2011 o wszczęciu postępowania administracyjnego w sprawie wpisania do rejestru zabytków układu urbanistycznego Bydgoskiego Przedmieścia i Rybaków w Toruniu, Biuletyn Informacji Publicznej, Wojewódzki Urząd Ochrony Zabytków w Toruniu; nr rejestru zabytków: A/1596. 
naruszenia dóbr osobistych. Zakaz fotografowania obejmuje jednak wyłącznie budynki ważne dla obronności i bezpieczeństwa państwa, natomiast obiekty znajdujące się w tzw. przestrzeni publicznej można uwieczniać, a ich zdjęcia publikować bez obaw ${ }^{5}$. Problemem staje się wprawdzie brak jasnej definicji „przestrzeni publicznej”, a także możliwość naruszenia prawa do prywatności - jednak w tym wypadku zasadnicze znaczenie ma wyjątkowy status fotografowanych obiektów. Są one formalnie „zabytkowe” m.in. wówczas, jeśli uznane zostały za pomnik historii, wpisane do rejestru zabytków czy ujęte w gminnej lub wojewódzkiej ewidencji zabytków, zatem dostęp do nich gwarantuje konstytucja. Należy jednak odnotować, że jest to zawiła kwestia prawna i wiele zależy od interpretacji przepisów.

W tworzeniu Katalogu wzięło udział piętnastu studentów pracujących w zróżnicowanych pod względem wielkości zespołach (od jednej osoby w przypadku Mokrego, do pięciu w przypadku historycznego Bydgoskiego Przedmieścia). Wyniki ich pracy zostały opublikowane w Internecie - dzięki czemu zdjęcia są łatwe do odnalezienia i ogólnodostępne. Charakter i budowa katalogu umożliwiają szybkie wyszukiwanie obiektów oraz ich identyfikację, bez konieczności udawania się na miejsce. Aby obejrzeć zebrany materiał należy w witrynie www.knsk.umk.pl w zakładce „projekty” wybrać z listy „Katalog architektury drewnianej w Toruniu", a następnie, w celu przejścia do strony głównej katalogu, kliknąć na mapę. W pasie zakładek „albumy”, tworzącym lewy margines, dostępne są foldery - ich nazwy odpowiadają nazwom dzielnic Torunia. Wybranie jednego z folderów skutkuje przekierowaniem do strony, na której materiał zdjęciowy pogrupowany jest w ramach ulic, zgodnie $\mathrm{z}$ rosnącą numeracją budynków (il. 1). Wybrana metoda porządkowania zdjęć gwarantuje wygodny i czytelny sposób prezentacji materiału fotograficznego. Zdjęcia przedstawiają ogólny widok na obiekt (il. 2), w przypadku występowania interesującego detalu (il. 3) zamieszczane są również dodatkowe fotografie.

\section{Stan architektury szkieletowej w Toruniu}

Budynki w konstrukcji muru pruskiego nikną niebywale szybko, zaś proces ich fotografowania i katalogowania staje się swoistego rodzaju wyścigiem z czasem. Przykładem tego może być obiekt przy Szosie Chełmińskiej 71 został on udokumentowany $w$ ostatniej chwili, w momencie rozbiórki, już bez dachu (il. 4). Bez wątpienia wiele z tych domów charakteryzuje się wybitnymi walorami, jak np. budynek przy ul. Bydgoskiej 50/52, który nazywany bywa „se-

\footnotetext{
5 Ustawa z dnia 4 lutego 1994 r. o prawie autorskim i prawach pokrewnych, art. 33; Dz.U. 1994, Nr 24, poz. 83.
} 
cesyjną perełką” Bydgoskiego Przedmieścia. Wyjątkowa willa, zgodnie z wynikami badań Bartosza Zalewskiego, powstała w 1899 roku według projektu berlińskiego biura architektonicznego Erdmann und Spindler ${ }^{6}$. Stan tego budynku jest doskonale znany mieszkańcom Bydgoskiego Przedmieścia, a także wielu miłośnikom zabytków. Przytaczając cytat z internetowego wydania Nowości: „Sytuację pogarsza m.in. to, że mieszkańcy mocno podupadłej perły Bydgoskiego Przedmieścia są wykwaterowywani, w pustych pomieszczeniach wandale czują się bezkarni. [...] Przypadek ten nie jest odosobniony. Aby znaleźć kolejne, wystarczy przejść się po Bydgoskim Przedmieściu. Problem Bydgoskiej 50/52 nie jest niczym nowym na tym toruńskim łez padole, jednak tu przyszłość budynku wydaje się szczególnie niepewna, a chodzi o obiekt nie tylko niezwykle cenny ze względów architektonicznych, lecz również historycznych. Tu chociażby znajdował się jeden z pierwszych akademików toruńskiego uniwersytetu, gdzie zresztą pracownicy naukowi mieszkali pod jednym dachem ze studentami”7.

Innym przykładem może być prowadzona właśnie akcja wyburzania budynków pod trasę staromostową - zniszczone mają zostać obiekty od ulicy Bema aż do Polnej (zakończono już wyburzanie pod trasę średnicową, odc. północny) - mającą biec przez Chełmińskie Przedmieście, które w wyniku tych zabiegów stopniowo traci swój i tak tylko częściowo zachowany charakter. Niektóre ze skatalogowanych obiektów zniknęły z krajobrazu miasta. Te wciąż zachowane znajdują się między innymi na osiedlu Mokre oraz na Jakubskim Przedmieściu.

Dobrym materiałem dla podjęcia szerszej dyskusji nie tylko na temat Katalogu, ale przede wszystkim stosunku do architektury szkieletowej i jej znaczenia w Toruniu jest Winnica ${ }^{8}$. Jej szczególny charakter związany jest z położeniem wzdłuż terasy Wisły, w wyniku czego zabytkowa zabudowa skupia się głównie w części wschodniej, wzdłuż ul. Winnica (po północnej stronie budynki sytuowane są w dwóch, a niekiedy w trzech liniach zabudowy). Znacząca jest również historia tej części miasta ( $w$ okresie, z którego pochodzą będące przedmiotem zainteresowania obiekty - to jest z końca XIX i początków XX wieku - przedmieście zamieszkiwała społeczność rybacka). Zabytkowa zabudowa Winnicy jest niska (jedno- lub dwukondygnacyjna); są to budynki jedno- lub wielorodzinne usytuowane na stosunkowo obszernych działkach, wśród zieleni, z zachowany-

6 Szymon SPANDOwSKI, W Toruniu rozpadają się dzieła berlińskich mistrzów secesji, „Nowości Dziennik Toruński" e-wydanie: http://nowosci.com.pl/323041 (dostęp: 26 IV 2015).

7 Szymon SpandowskI, Kamienica przy Bydgoskiej 50/52 nadal jest demolowana, „Nowości Dziennik Toruński” e-wydanie: http://nowosci.com.pl/301358 (dostęp: 26 IV 2015).

8 Dzielnica usytuowana wzdłuż prawego brzegu Wisły, na wschód od zespołu staromiejskiego (zarówno w niektórych źródłach historycznych, jak i w obecnych badaniach nazywana Starym Jakubskim Przedmieściem), z układem komunikacyjnym ograniczonym do sześciu ulic: Winnica, Winna, Ścieżka Szkolna, Powiśle, Nad Zatoką i Rzeczna. 
mi pierwotnymi elewacjami (pozbawionymi detalu) oraz centralną osią symetrii, na której znajduje się wejście. Niestety, wzrost zainteresowania deweloperów tą częścią miasta w ostatnich latach znacząco wpłynął na jej charakter. Dotychczasowa architektura wypierana jest przez nową zabudowę - murowaną i wielokondygnacyjną, działki zostają ściślej zagospodarowywane, a unikatowy charakter dzielnicy zatraca się w zastraszającym tempie. Co istotne - temat potrzeby ochrony architektury tego typu podnoszony był niemal od półwiecza. Już w latach 1967-1970 powstał projekt utworzenia Muzeum Wiślanego przy ul. Winnica w ramach "Nadwiślańskiego Parku - Winnica w Toruniu” autorstwa Marii Znamierowskiej-Prüfferowej9. Był on częścią projektu utworzenia sieci muzeów w województwie bydgoskim, zorganizowanych $w$ „zabytkowych zagrodach i chatach pozostawionych in situ i stworzenia z nich [...] tętniących życiem placówek kulturalno-oświatowych, a zarazem [...] atrakcyjnych punktów turystycznych ${ }^{10 ”}$. Projekt Parku był rozbudowany: obejmował obszar 17 hektarów, a jego szeroko zakrojona koncepcja funkcjonalna uwzględniała wszelkie potrzeby zarówno mieszkańców, jak i turystów. Muzeum Wiślane miało być zlokalizowane w kilku zaadaptowanych na ten cel zabytkowych budynkach na dolnej terasie. Miały to być m.in. dwa budynki mieszkalne przekształcone na sale wystawowe z ekspozycjami, związanymi z zajęciami wodnymi na Wiśle - rybołówstwem, flisactwem oraz żeglugą, a oprócz tego pracownie muzealne, punkt informacyjny, gospoda i rekonstruowany dom rybaka z wyposażeniem rybackim. Chciano także wybudować przystań na Wiśle z pływającymi jednostkami muzealnymi w postaci barek, łodzi i tratw. Na górnej terasie znalazłby się zespół hotelowo-gastronomiczny. Planowano także przeniesienie kilku zabytkowych budynków o tej samej stylistyce z przedmieść Chełmińskiego i Bydgoskiego. Początkowo projekt uzyskał poparcie Komitetu Kultury Fizycznej i Sportu w Warszawie, Ministerstwa Kultury i Sztuki, władz administracyjnych w Toruniu oraz Wojewódzkiego i Miejskiego Konserwatora Zabytków. Wizjonerska i innowacyjna koncepcja muzeum na wolnym powietrzu miała na celu oddanie charakteru życia zamieszkujących Winnicę torunian, z podkreśleniem ogromnego znaczenia Wisły w ich codziennej egzystencji. Realizacja przedsięwzięcia okazała się nierealna: wymagała bowiem ogromnych nakładów finansowych. Problemem okazało się również rozwiązanie sytuacji mieszkaniowej ludności przewidzianej do wykwaterowania z obszaru objętego projektem.

Kwestia ochrony budownictwa Winnicy wraz z innymi XIX-wiecznymi zabytkami toruńskich przedmieść i pomysł utworzenia skansenu powracała na

9 Maria ZnAmierowska-Prüfeerowa, Zabytki budownictwa ludowego w Polsce i ich rola we współczesnym krajoznawstwie i turystyce, „Ochrona Zabytków”, 20, 1977, nr 4, s. 16; Roman TUBAJA, Niezrealizowana koncepcja ochrony in situ zespolu architektonicznego przy ul. Winnica w Toruniu, „Acta Scansenologica”, 10, 2010, s. 147.

10 Znamierowska-PrǘEerowa 1977, s. 16. 
przestrzeni lat, jednak za każdym razem napotykała podobne przeszkody. Skalę przemian niech zobrazuje zestawienie, opracowane na podstawie pracy Bolesława Sądowskiego Toruń. Jakubskie Przedmieście: Studium historyczno-konserwatorskie z 1984 roku $^{11}$ oraz prezentowanego Katalogu. Zachowane przy ul. Winnica budynki w konstrukcji drewnianej i szkieletowej w przeważającej części pochodzą z ostatnich czterech dekad XIX wieku. W przywołanym Studium... jako należące do wspomnianych wymienione zostały obiekty o następujących numerach: 10, 10a, 12, 12a, 16, 18a, 20, 22, 24, 28, 32, 34. Do analizowanej grupy zalicza się również zabudowa mieszkaniowa powstająca po roku 1900 (lub do zakończenia pierwszej wojny światowej), będą to numery: 19, 25, 26, 27, 35/39. Budynki te zostały poddane wartościowaniu przez autora pracy i przyporządkowane do dwóch kategorii:

a) budynki o średniej wartości zabytkowej: 10, 10a, 12, 12a, 18a, 19, 20, 22, 24, $26,28,32,34$,

b) budynki o niskiej wartości zabytkowej: 27, 35/39.

W znacznej części omawiana grupa cechowała się zatem - przynajmniej w tamtym okresie - średnią wartością zabytkową ${ }^{12}$. Budynkami zachowanymi obecnie są domy pod numerami 10,10a, 16, 18a, 19, 20, 22, 24, 26, 34 (il. 5). W przedostatniej dekadzie XX wieku było ich zatem siedemnaście, po trzydziestu latach zostało zaledwie dziesięć. Wysunięty przez Marię Znamierowską-Prüfferową pomysł, choć należy go uznać za wartościowy i w pełni wykorzystujący walory architektoniczne i krajobrazowe miejsca, dziś nie jest już więc możliwy do zrealizowania.

\section{Podsumowanie}

Zamysłem autorek projektu było stworzenie przyczynku do dalszej dyskusji nad przyszłością wielu toruńskich obiektów, zabytków o nie tak dawnej, jak średniowieczna, metryce. Przyglądając się podziałowi nakładów finansowych, uwadze skupionej tylko na wybranych elementach składających się na całokształt architektonicznego dziedzictwa Torunia (ograniczającej się głównie do Starego Miasta) oraz ruchowi turystycznemu można zaobserwować kuriozalną sytuację, w której o wartości poszczególnych budynków w oczach decydentów przesądza wyłącznie ich wiek oraz to, jak wpasowują się w wypracowany wizerunek „marki Torunia”. W zaistniałej sytuacji przede wszystkim należy zadać sobie pytanie, czy kierunek zmian nie jest z perspektywy konserwatorskiej aktem

11 Bolesław SĄDowski, Toruń. Jakubskie Przedmieście: Studium historyczno-konserwatorskie, Toruń 1984.

TAMżE, s. 35-40. Budynek pod nr. 16 nie został ujęty w opracowaniu. 
kapitulacji? Czy za kilka dekad w należytej kondycji utrzymane nie pozostaną jedynie obiekty średniowieczne, zaś świadectwem istnienia pozostałych staną się wyłącznie fotografie? Czy mimo chęci zachowania budynków uznawanych za „Średniej wartości”, duży fragment materialnej historii miasta nie przestanie istnieć na zawsze, gdyż górę wezmą krótkoterminowe interesy realizowane kosztem zabytków?

\author{
Daria Jagiełło, Magdalena Kumorowicz, \\ Paulina Szczurek, Kamila Witkowska \\ Faculty of Fine Arts, Nicolaus Copernicus University in Toruń
}

\title{
Catalogue of wooden architecture of Torun - summary of the project of the Conservation Student's Research Circle
}

The Catalogue of Wooden Architecture in Torun was compiled in the years 20112013 by the Conservation Students' Research Circle at the Department of Conservation of the Faculty of Fine Arts of the University of Torun. It was created in response to the continuing process of destruction of wooden architecture in the city. The marginal treatment of wooden architecture can be observed by taking a look at the state of preservation of wooden buildings found in the suburbs of Torun. In the Bydgoszcz Suburb wooden buildings of high quality are slowly falling apart. In the Chełmno Suburb, following demolitions necessary for the construction of a new road, the whole area is losing its character. The conditions of buildings on the Winnica street is also an example of this process - the number of wooden buildings there has decreased significantly over the last few decades. The online photo database created by the students covers the whole administrative area of the city. The photographs have been put in order in accordance to the city districts and suburbs, by street name. The photographs present the entire view of the building and of the architectural detail, when it is present. The Catalogue is a publicly available iconographic source, which can serve as a starting point for further research, and can hopefully serve to encourage people to familiarize themselves with the slowly disappearing wooden architecture of Torun. 


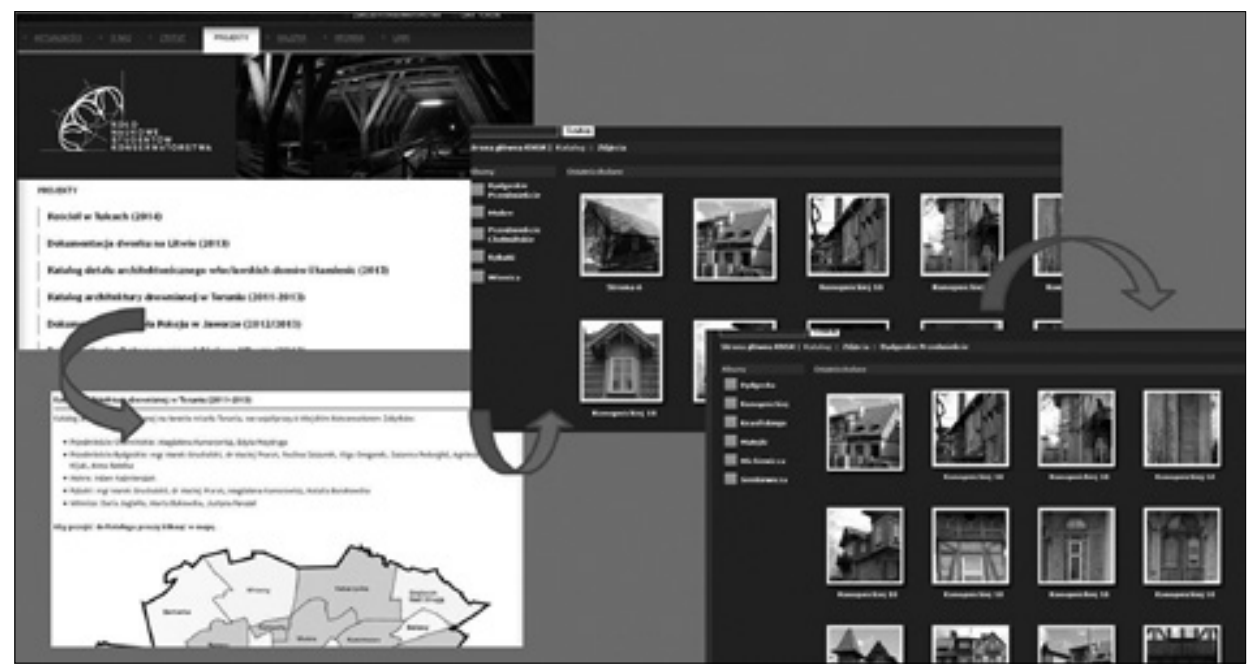

Il. 1. Schemat korzystania z Katalogu Architektury Drewnianej Torunia 


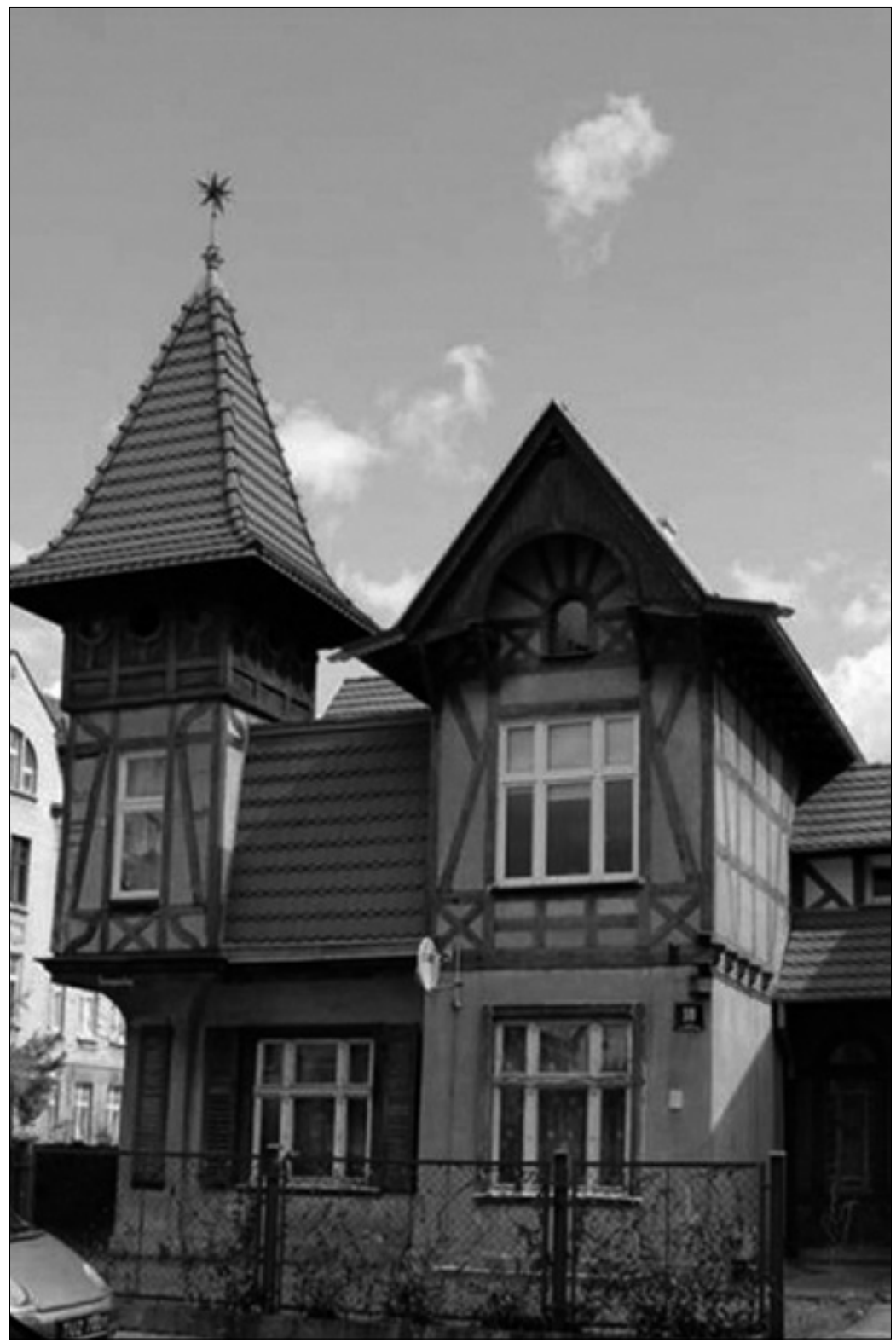

Il. 2. TonuŃ, willa przy ul. Marii Konopnickiej 18, widok ogólny obiektu. Fot. O. Gregorek, P. Szczurek 


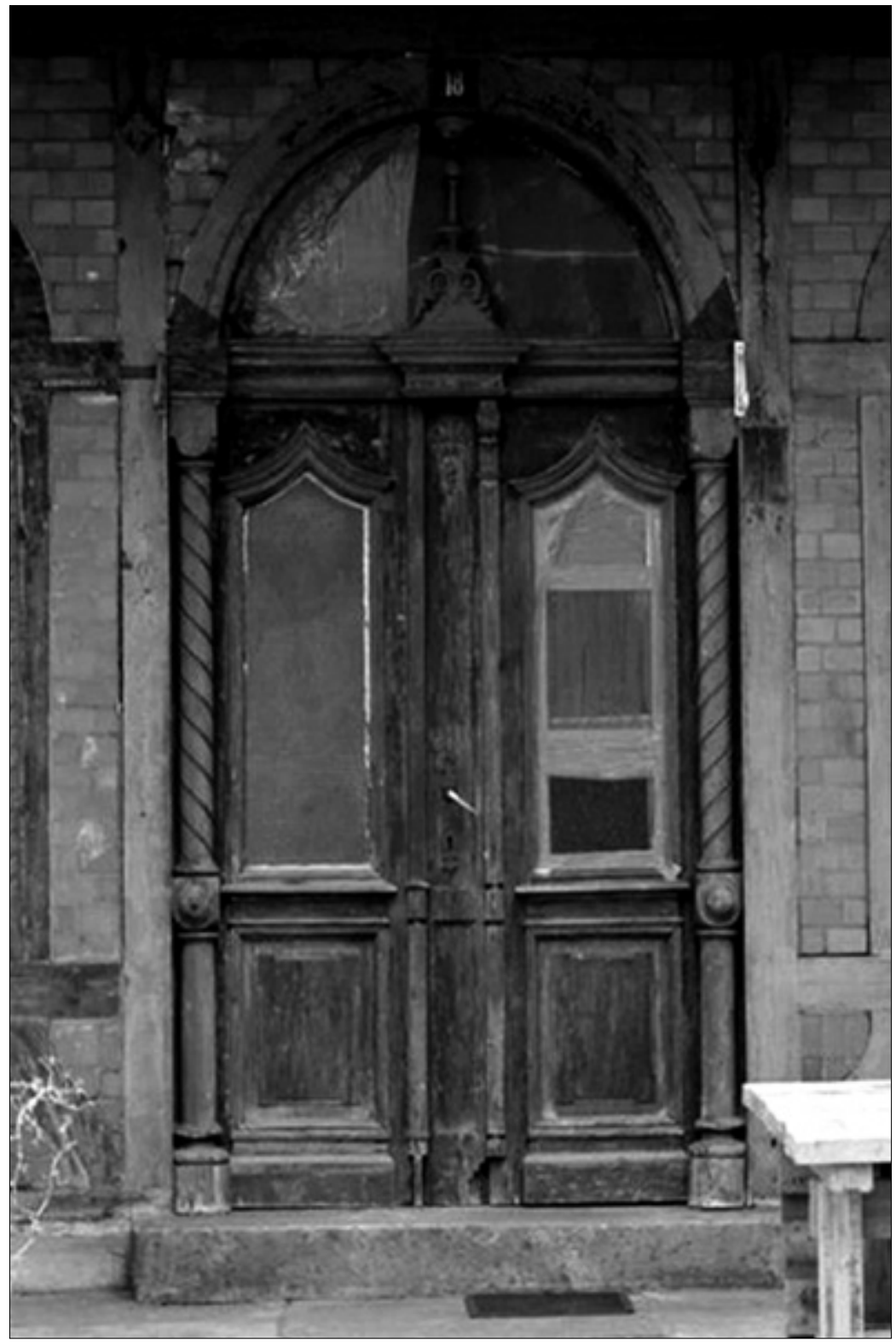

Il. 3. ToRuń, willa przy ul. Marii Konopnickiej 18, detal. Fot. O. Gregorek, P. Szczurek 


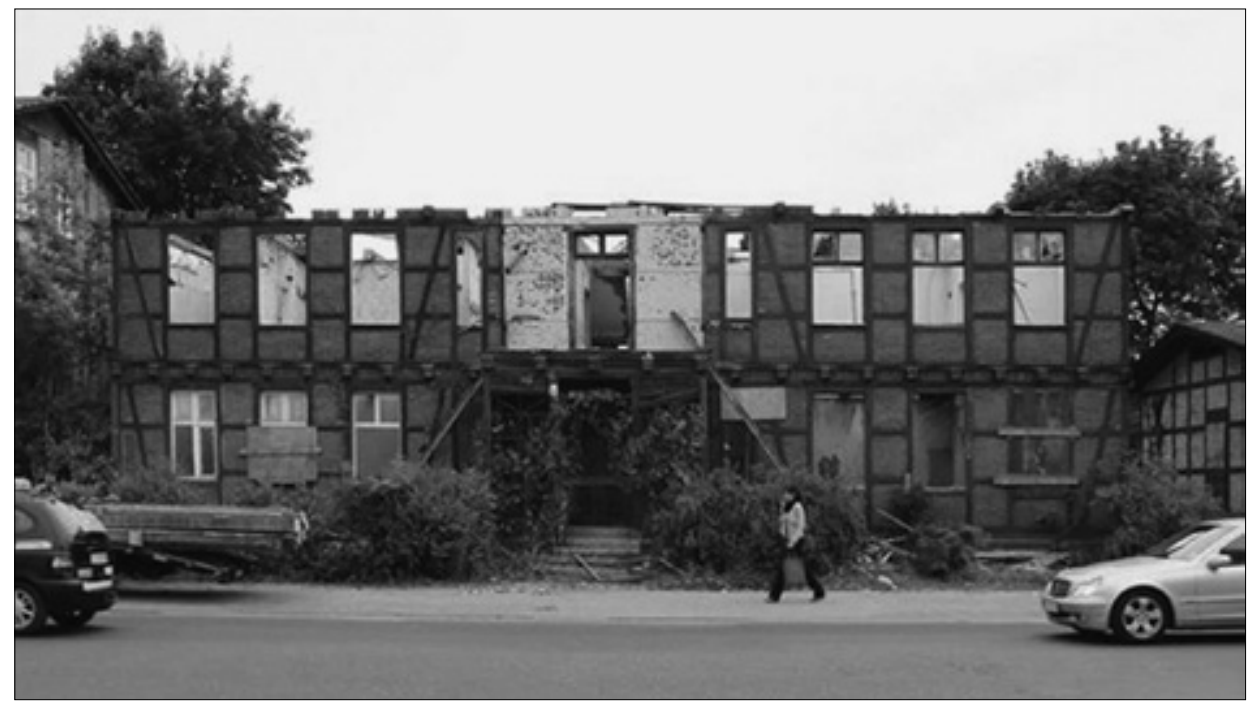

Il. 4. ToruŃ, budynek przy ul. Szosa Chełmińska 71, udokumentowany w trakcie rozbiórki. Fot. M. Kumorowicz

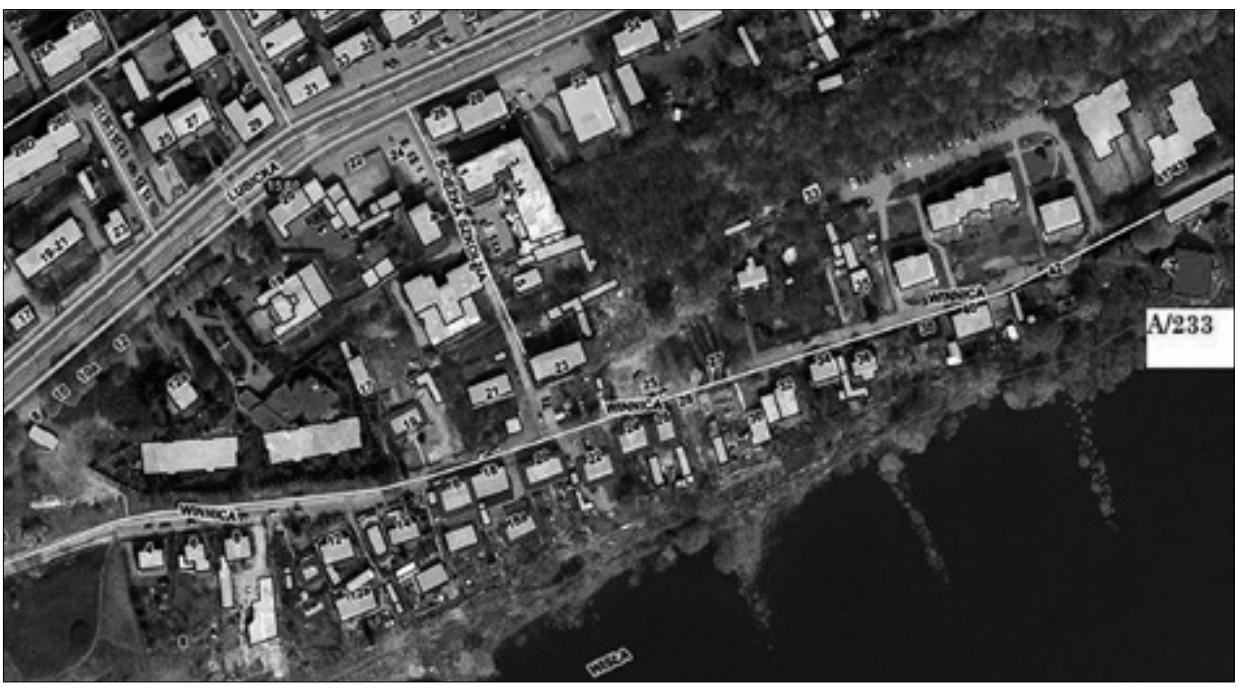

Il. 5. ToruŃ, ul. Winnica, budynki osady flisaczej wzniesione w konstrukcji muru pruskiego, które przetrwały do dnia dzisiejszego, opracowano na podstawie: http://geoportal.gov.pl/ 